\title{
Topographic control of snow distribution in an alpine watershed of western Canada inferred from spatially-filtered MODIS snow products
}

\author{
J. Tong ${ }^{1}$, S. J. Déry ${ }^{2}$, and P. L. Jackson ${ }^{2}$ \\ ${ }^{1}$ Natural Resources and Environmental Studies, University of Northern British Columbia, Prince George, \\ BC, V2N 4Z9, Canada \\ ${ }^{2}$ Environmental Science and Engineering Program, University of Northern British Columbia, Prince George, \\ BC, V2N 4Z9, Canada \\ Received: 15 July 2008 - Published in Hydrol. Earth Syst. Sci. Discuss.: 26 August 2008 \\ Revised: 2 February 2009 - Accepted: 2 March 2009 - Published: 13 March 2009
}

\begin{abstract}
A spatial filter (SF) is used to reduce cloud coverage in Moderate Resolution Imaging Spectroradiometer (MODIS) 8-day maximum snow cover extent products (MOD10A2) from 2000-2007, which are obtained from MODIS daily snow cover extent products (MOD10A1), to assess the topographic control on snow cover fraction (SCF) and snow cover duration (SCD) in the Quesnel River Basin (QRB) of British Columbia, Canada. Results show that the SF reduces cloud coverage and improves by $2 \%$ the accuracy of snow mapping in the $\mathrm{QRB}$. The new product developed using the SF method shows larger SCF and longer SCD than MOD10A2, with higher altitudes experiencing longer snow cover and perennial snow above $2500 \mathrm{~m}$. The gradient of SCF with elevation $(\mathrm{d}(\mathrm{SCF}) / \mathrm{d} z)$ during the snowmelt season is $8 \%(100 \mathrm{~m})^{-1}$. The average ablation rates of SCF are similar for different $100 \mathrm{~m}$ elevation bands at about $5.5 \%$ (8 days $)^{-1}$ for altitudes $<1500 \mathrm{~m}$ with decreasing values with elevation to near $0 \%(8 \text { days })^{-1}$ for altitudes $>2500 \mathrm{~m}$. Different combinations of slopes and aspects also affect the SCF with a maximum difference of $20.9 \%$ at a given time. Correlation coefficients between SCD and elevation attain $0.96(p<0.001)$. Mean gradients of SCD with elevation are $3.8,4.3$, and 11.6 days $(100 \mathrm{~m})^{-1}$ for the snow onset season, snowmelt season, and entire year, respectively. The SF decreases the standard deviations of SCDs compared to MOD10A2 with a maximum difference near 0.6 day, 0.9 day, and 1.0 day for the snow onset season, snowmelt season, and entire year, respectively.
\end{abstract}

Correspondence to: J. Tong

(jtong@unbc.ca)

\section{Introduction}

Snow plays a vital role in the energy and water budgets of drainage basins in northern British Columbia (BC) and many other mountainous regions. For instance, snowmelt contributes up to $90 \%$ of the annual runoff in high elevation basins of the Rocky Mountains, United States (Schmugge et al., 2002). In northern mountainous areas, snow supplies large amounts of water for human consumption (Barnett et al., 2005). A number of studies have shown that, for the latter half of the 20th century, snow has decreased significantly during spring over North America and Eurasia in response to rising air temperatures (Brown, 2000; Stone et al., 2002; Groisman et al., 2004; Mote, 2006; Déry and Brown, 2007). The snow cover extent (SCE) and snow cover duration (SCD) are important parameters for various hydrologic models to predict the seasonal water supply, runoff, and flooding risk in watersheds dominated by snowmelt (Hall, 1988; Jain and Lall, 2000; Yang et al., 2003).

The heterogeneous distribution of snow cover at the local to regional scale arises from variability in meteorological (precipitation, temperature, radiation and wind), topographical (elevation, slope, and aspect), and vegetative controls, among others. In mountainous regions, elevation is often presumed to be the dominant factor affecting snow cover distribution. Snow surveys are useful to determine the relationship between fixed point snow observations with the mean values in a local area (Neumann et al. 2006); however, this approach is not suitable in a large region with complex topography. Therefore, remote sensing snow cover products have been widely adopted to assess snow distributions in many areas. For instance, the spring snow cover in the Canadian Arctic

Published by Copernicus Publications on behalf of the European Geosciences Union. 
is evaluated according to the National Oceanic and Atmospheric Administration (NOAA) weekly snow cover dataset (Wang et al., 2005). Spatial gradients in spring SCD in the Canadian Arctic over a range of elevations from 1 to $700 \mathrm{~m}$ are assessed from the NOAA weekly snow cover dataset by Brown et al. (2007). Pu et al. (2007) use the Moderate Resolution Imaging Spectroradiometer (MODIS) snow data products at $0.05^{\circ}$ resolution (MOD10C2) to evaluate the seasonal variations of snow cover over the Tibetan Plateau. So far, the snow cover distribution in the high elevation sub-boreal forest of western Canada has received limited attention owing to the complex topography and the associated limited accuracy of remote sensing products. Therefore, the Quesnel River Basin (QRB), a representative, high elevation watershed in the sub-boreal forest of BC, Canada, is selected as a test site to first validate the remote sensing products and then to analyze the relationships between complex topography and snow cover.

MODIS has global daily snow cover products (MOD10A1) and global 8-day maximum snow cover products (MOD10A2) at $500 \mathrm{~m}$ resolution, which are highly suitable to analyze the snow cover within an area of about $10000 \mathrm{~km}^{2}$ (Hall et al., 2002). Snow can be discriminated from other features such as clouds due to higher Normalized Difference Snow Index (NDSI) values (Hall et al., 1998). The MODIS snow maps use a conservative cloud mask to determine clouds with the MODIS cloud mask data product (MOD35_L2) (Riggs et al., 2006). Since optical remote sensing cannot obtain signals of the overcast surface, cloudiness strongly affects the quality of the snow cover products. The main goal of this study is to determine the topographic control on snow distribution in a mountainous watershed of western Canada based on MODIS snow products from February 2000 to December 2007. To this end, a spatial filter (hereinafter SF) method is evaluated by comparing the means and standard deviations of SCDs and snow cover fractions (SCFs) retrieved from both the original and filtered MOD10A2 products. We first reduce cloudiness with a SF method to reclassify the MOD10A2 data. Then the accuracy of the SF is assessed using ground-based observations followed by an analysis of the relationships between topography, SCF, and SCD based on the original and filtered snow products. Owing to the sparseness of in-situ snow depth stations in northern $\mathrm{BC}$, remotely sensed snow products are particularly useful to analyze the topographic control on snow distribution. Our spatial filter is a simplified method compared to others (e.g., Parajka and Blöschl, 2008) to improve the MODIS snow products but provides improved accuracy for this application.

\section{Study area}

The QRB, which is centered near $52.5^{\circ} \mathrm{N}$ and $121^{\circ} \mathrm{W}$ in the northern part of the Fraser River Basin, BC, covers an area of

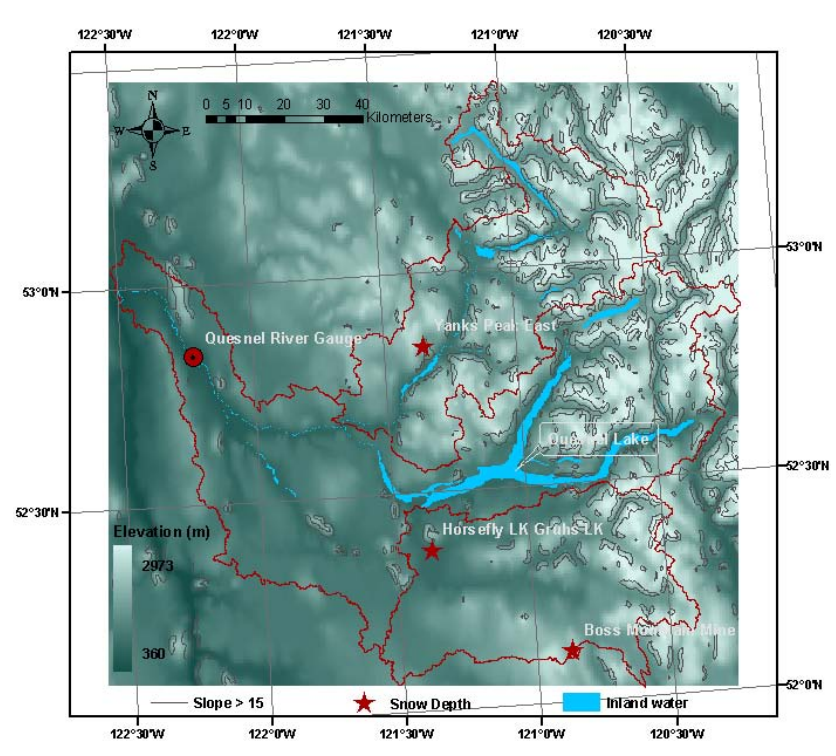

Fig. 1. Topographic map of the Quesnel River Basin region with the basin outlined. Slopes $>15^{\circ}$ are shown within light lines on the eastern half of the map.
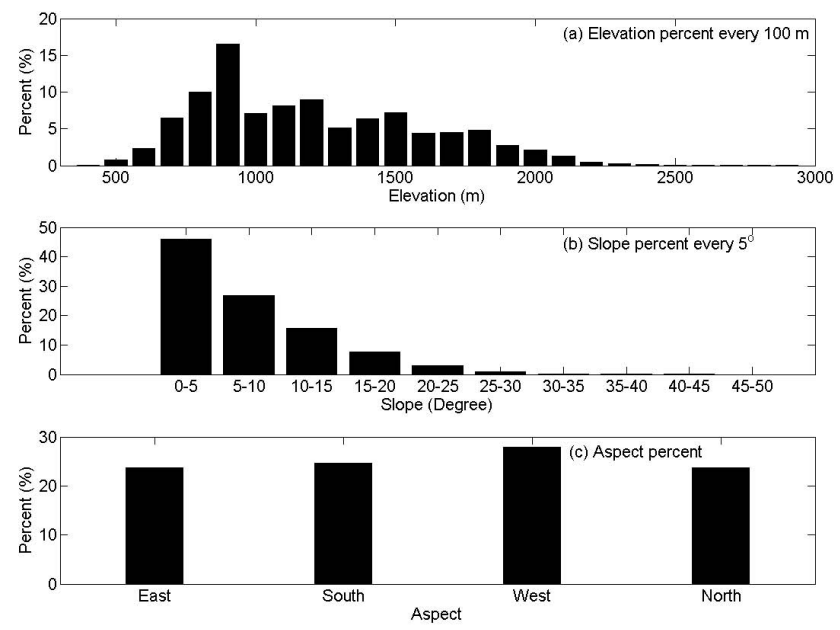

Fig. 2. The distribution of terrain in the Quesnel River Basin by (a) elevation, (b) slope and (c) aspect calculated from the Global Land One-kilometer Base Elevation (GLOBE) digital elevation model.

about $12023 \mathrm{~km}^{2}$ with a wide range of topography, land use and meteorological conditions (Fig. 1). The total areas of elevation bands $<1000 \mathrm{~m}, 1000-1500 \mathrm{~m}, 1500-2000 \mathrm{~m}, 2000$ $2500 \mathrm{~m}$, and $>2500 \mathrm{~m}$ account for: $36.1 \%, 35.6 \%, 23.8 \%$, $4.25 \%$, and $0.15 \%$ of the basin, respectively, with an overall mean of $1370 \mathrm{~m}$. The total areas of slopes $<5^{\circ}, 5^{\circ}-15^{\circ}$, and $>15^{\circ}$ account respectively for $45.8 \%, 42.4 \%$, and $11.8 \%$ of the watershed area, with an area off about $40 \mathrm{~km}^{2}(0.35 \%)$ over $40^{\circ}$. The distributions of west, south, east, and north aspects are similar at about 25\% (Fig. 2). Quesnel Lake, a dominant feature of the basin, covers an area of about $271 \mathrm{~km}^{2}$ at 
a mean elevation of $\approx 730 \mathrm{~m}$. To the east lies the headwaters of the watershed that are covered mainly by alpine tundra and glaciers, with old growth forests below the treeline (i.e. $<1700 \mathrm{~m}$ ). Further west are several towns, young forest growth and agricultural regions.

\section{Data and methods}

A MODIS instrument on-board the Earth Observing System (EOS) Terra satellite was launched on 18 December 1999 and orbits from north to south across the equator at $\sim$ 10:30 a.m. local time. The SNOWMAP algorithm developed for MODIS allows the automatic generation of SCE maps at a $500 \mathrm{~m}$ scale (Hall et al., 1995, 2002). Daily or 8day global snow cover products with $500 \mathrm{~m}$ to $\sim 5 \mathrm{~km}$ spatial resolution are thus available through the Distributed Active Archive Center at the National Snow and Ice Data Center (NSIDC; http://nsidc.org).

The MODIS data used here include daily snow cover maps (MOD10A1) and 8-day maximum snow cover maps (MOD10A2) from February 2000 to December 2007. To date, the transition from Version 4 (V4) to Version 5 (V5) of these products is not yet complete; therefore, we mainly use V5 data in combination with some V4 data, noting that there is less than $1 \%$ difference between the two versions (Hall, personal communication, 2008). V5 data begin on 23 March 2000 and end on 13 September 2005 and also cover all of 2007. V4 data span from 24 February 2000 to 22 March 2000 and from 14 September 2005 to 31 December 2006. Tile h10v03 covers the entire study area of the QRB. The MODIS Reprojection Tool (MRT) is used to resize and reproject the tile data to BC Albers equal area conic projection with batch processing code. The digital elevation model (DEM) used in this study is the Global Land One-kilometer Base Elevation (GLOBE) data set provided by the National Geophysical Data Center (NGDC; http://www.ngdc.noaa.gov/mgg/topo/ globe.html), which is interpolated to the $500 \mathrm{~m}$ resolution of the MOD10A products by a nearest neighbor interpolation method.

Even though the accuracy of the MODIS snow cover maps is about $90 \%$ in cloud-free pixels (Déry et al., 2005; Zhou et al., 2005; Hall and Riggs, 2007), clouds can prevent the optical sensors from detecting snow cover for extended periods, lowering the temporal resolution of the data. The 8-day mean cloud coverage in the QRB according to MOD10A1 ranges from $40 \%$ to $85 \%$, preventing a useful application of daily snow cover maps to the area. However, the 8-day maximum snow cover map forms a temporal filter that decreases cloud coverage with maximum value from $80 \%$ (MOD10A1) to $14 \%$ (MOD10A2) in the QRB (Fig. 3). However, about $20 \%$ cloud coverage remains during winter such that the SF is adopted to decrease the cloud coverage and improve the accuracy of snow mapping of MOD10A2 in the QRB. The relationship between annual cloud coverage days and eleva-
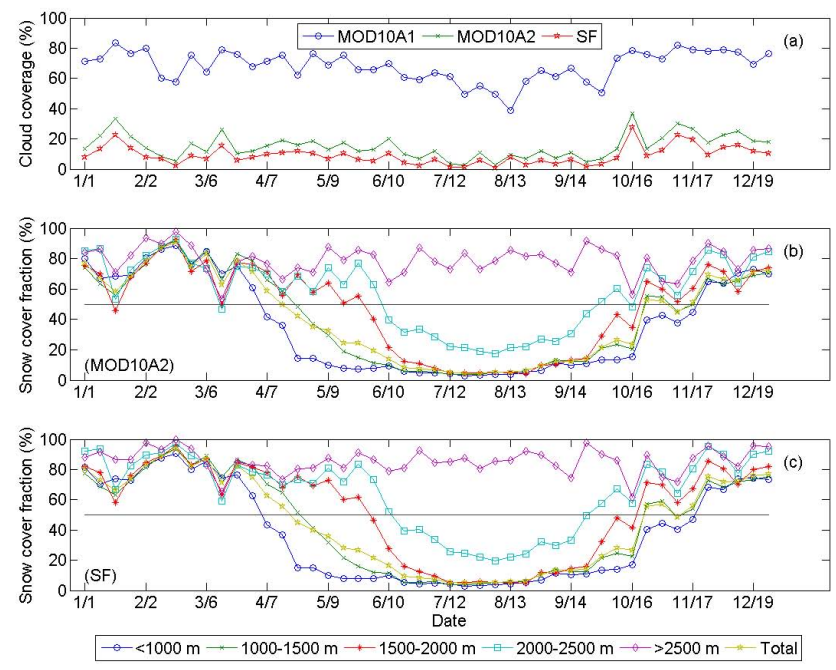

Fig. 3. (a) The average annual cycle of cloud coverage of different snow products; the (b) MOD10A2 and (c) spatial filtered snow cover fraction (SCF) distribution in different elevation bands, 2000 2007. The solid line in (b) and (c) denotes a 50\% SCF.

tion shows that annual cloud coverage days increase with elevation (not shown).

Tong et al. (2009) describe in detail the application of the $\mathrm{SF}$ to the QRB, so only a brief summary of this technique is described here. In the SF method, the snow maps are reclassified as snow, no snow, and cloud. A cloud-covered pixel is replaced by the majority of non-cloud pixels in the eight closest neighborhood pixels. If the number of pixels with snow equals the number without snow, the center pixel is defined as snow. However, if all of the eight closest neighborhood pixels are cloud-covered, the center pixel is still classified as cloudy. The accuracy of the SF products over 20002007 is evaluated following the method used by Parajka and Blöschl (2008) with three fixed point snow depth observations in the QRB (Fig. 1). Based on these measurements, the SF improves the accuracy of the snow mapping by $\approx 2 \%$ over the original MOD10A2 data (Table 1). At the Horsefly Lake/Gruhs Lake station, situated at an elevation of $777 \mathrm{~m}$, the accuracy of the SF product is about $91.5 \%$. However, the accuracy of the SF data declines with elevation, with values of $82.7 \%$ at Boss Mountain Mine (1460 m) and $74.2 \%$ at Yanks Peak $(1670 \mathrm{~m})$, respectively owing to the more complex topography in the higher elevations of the basin. In sum, the SF decreases the cloud coverage to about $10 \%$ in the QRB while increasing its accuracy (Fig. 3).

In this paper, the SCF for a given elevation band is defined as the ratio of snow-covered area to the total elevation band area. A mean annual cycle of 8-day SCF is then computed based on the 2000 to 2007 MODIS snow cover data. In addition, SCF between every $100 \mathrm{~m}$ elevation band and different combinations of slopes and aspects are also calculated (Table 2). As shown in Fig. 3, according to the SCF annual 
Table 1. Accuracy of MODIS snow products based on the comparison between MOD10A2, spatial filtered products and in-situ observations at three different stations. A threshold snow depth of $2 \mathrm{~cm}$ is used to classify snow at in-situ stations.

\begin{tabular}{lllll}
\hline Stations & Coordinates & Elevation, $\mathrm{m}$ & MOD10A2, \% & SF, \% \\
\hline Horsefly Lake/Gruhs Lake & $52.37^{\circ} \mathrm{N}, 121.37^{\circ} \mathrm{W}$ & 777 & 88.9 & 91.5 \\
Boss Mountain Mine & $52.12^{\circ} \mathrm{N}, 120.87^{\circ} \mathrm{W}$ & 1460 & 81.3 & 82.7 \\
Yanks Peak East & $52.83^{\circ} \mathrm{N}, 121.35^{\circ} \mathrm{W}$ & 1670 & 73.9 & 74.2 \\
\hline
\end{tabular}

Table 2. The percentage of area with different slopes and aspects in the Quesnel River Basin (\%).

\begin{tabular}{llllll}
\hline Aspect Slope & East & South & West & North & All \\
\hline$<5^{\circ}$ & 10.7 & 10.4 & 12.6 & 12.1 & 45.8 \\
$5^{\circ}-15^{\circ}$ & 10.1 & 11.3 & 11.7 & 9.3 & 42.4 \\
$>15^{\circ}$ & 2.9 & 2.9 & 3.6 & 2.4 & 11.8 \\
All & 23.7 & 24.6 & 27.9 & 23.8 & 100.0
\end{tabular}

cycle in the QRB, the snow onset season typically begins on 1 September and ends on 31 December, while the snowmelt season in the QRB typically ranges from 1 March to 30 June. SCD is defined as the number of days with snow cover on the ground in different snow seasons. The snowmelt season SCD is easier to determine than the end-dates of continuous snow cover owing to its discontinuous nature during the melt season. Also, Brown (2006) finds that SCD is a more sensitive indicator of change than the end date of continuous snow cover based on trends in the Mackenzie Basin since 1945. SCD is calculated for each pixel in the QRB. For a given pixel, if the snow products appear $N$ times as snow in the snow season, the SCD is $N \times 8$ (days). The standard deviation of $\mathrm{SCD}$ for a given pixel is calculated according to its 7 SCD values for each snow season from 2001 to 2007, since MODIS/Terra began to obtain data after 24 February 2000. The mean and standard deviation of SCD for each $10 \mathrm{~m}$ elevation band are calculated by averaging the SCD statistics of all pixels in the given $10 \mathrm{~m}$ elevation band. The changes of SCD with elevation $(z), \mathrm{d}(\mathrm{SCD}) / \mathrm{d} z$, are computed by averaging the differences of SCDs for every $100 \mathrm{~m}$ intervals according to the mean SCD for each $10 \mathrm{~m}$ elevation band.

\section{Results}

\subsection{Relationships between topography and SCF}

The annual cycle of SCF in $500 \mathrm{~m}$ elevation bands is calculated from the MOD10A2 and SF, respectively (Fig. 3). Compared to the original MOD10A2 product, the spatiallyfiltered data show more snow cover for the different elevation bands. The SF increases SCF in the QRB with max-
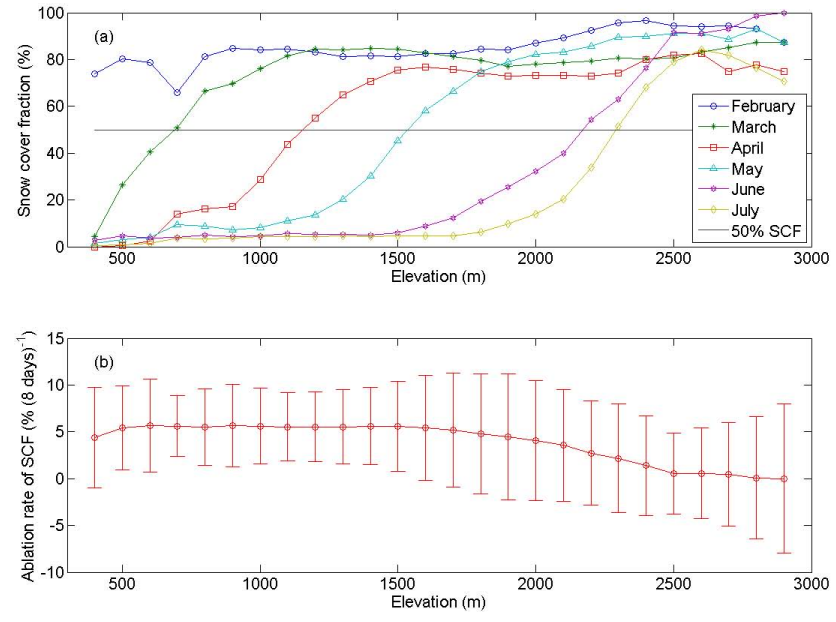

Fig. 4. (a) The mean elevational dependence of snow cover fraction (SCF) for the months of February to July 2000-2007. (b) The mean (points) and standard deviation (bars) of the rate of change in SCF at different elevations, 26 February to 26 June 2000-2007.

ima of $5.3 \%, 8.9 \%, 13.5 \%, 13.7 \%$, and $15.6 \%$ in the elevation bands of $<1000 \mathrm{~m}, 1000-1500 \mathrm{~m}, 1500-2000 \mathrm{~m}, 2000-$ $2500 \mathrm{~m}$, and $>2500 \mathrm{~m}$, respectively. The SF increases SCF in the QRB on average by $1.6 \%, 2.9 \%, 6.1 \%, 8.0 \%$, and $6.9 \%$ during the snow onset season and on average by $1.0 \%, 3.1 \%$, $7.8 \%, 8.9 \%$, and $6.7 \%$ during the snowmelt season in these 5 elevation bands. All SCFs at different elevations reach a maximum of over $95 \%$ on 18 February and a minimum of near zero on 5 August. Above $2500 \mathrm{~m}$, the SCFs remain near 95\% during winter and around $85 \%$ during summer, except for 7 of the 46 SCFs under $80 \%$, implying the presence of a perennial snow cover or glaciers. Even at altitudes $\leq 1000 \mathrm{~m}$, the method indicates about $2.5 \%$ snow cover in summer, an unrealistic feature of the MODIS data that may be attributed to the presence of fog, shadowing effects, and/or low illumination in valleys or on shaded slopes in mountainous terrain (Riggs and Hall, personal communication, 2008). Ablation of SCF begins earlier at lower elevations with the dates of $\mathrm{SCF}=50 \%$ occurring around 7 April, 23 April, 1 June, and 17 June in the elevation bands of $<1000 \mathrm{~m}, 1000-1500 \mathrm{~m}$, $1500-2000 \mathrm{~m}$, and 2000-2500 m, respectively. 

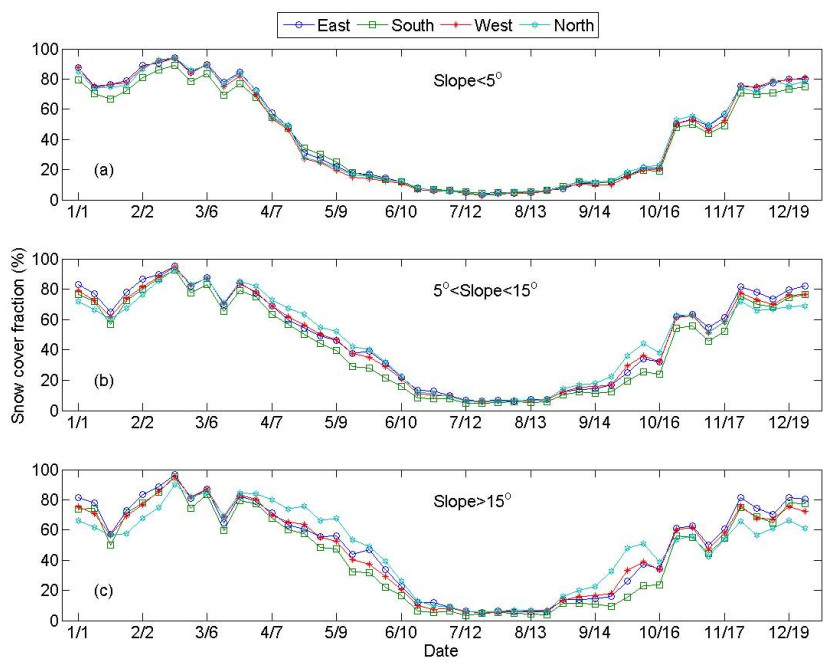

Fig. 5. The average annual cycle of snow cover fraction distribution in different slope and aspect bands, 2000-2007.

Figure 4a shows the effects of elevation on SCF depletion during the snowmelt season. At the end of February, almost all elevation bands have $\mathrm{SCF}>80 \%$; however, at the end of March, elevations $<1200 \mathrm{~m}$ begin to ablate out. At the different given times, the gradient of SCF with elevation $(\mathrm{d}(\mathrm{SCF}) / \mathrm{d} z$ ) from SCF of $10 \%$ to $80 \%$ during snowmelt seasons are similar with $8 \%(100 \mathrm{~m})^{-1}$. In addition, all the SCF depletion curves ranging from $10 \%$ SCF to $80 \%$ SCF with elevations are nearly parallel, implying the SCFs deplete along elevations at a similar rate even at different given times. Furthermore, between values of $10 \%$ to $80 \%$, the SCF exhibits a linear relationship with elevation, with a correlation coefficient of $0.98(p<0.001)$. Figure $4 \mathrm{~b}$ shows the average ablation rates of SCF from 26 February to 26 June and their standard deviations for every $100 \mathrm{~m}$ bands. At elevations from $500 \mathrm{~m}$ to $1500 \mathrm{~m}$, the average ablation rates of SCF are nearly identical at $5.5 \%(8 \text { days })^{-1}$. However, from $1500 \mathrm{~m}$ to $3000 \mathrm{~m}$, the average ablation rates of SCF decrease with elevation to near $0 \%$ ( 8 days $)^{-1}$ at the highest points in the basin. The bars show the standard deviations of the ablation rates of SCF every 8 days from 26 February to 26 June in the different $100 \mathrm{~m}$ elevation bands. The standard deviations are large compared to the average ablation rates of SCF, implying that these are highly variable. However, because the areas over $2000 \mathrm{~m}$ are small, the large standard deviations of ablation rates of SCF are perhaps caused by cloud coverage instead of the real melt of snow there. For every $100 \mathrm{~m}$ elevation band, 14 March always experiences the greatest ablation rate of SCF compared with other melt rates of SCF in the same elevation band. The average maximum ablation rate of

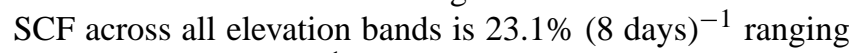

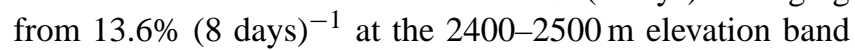

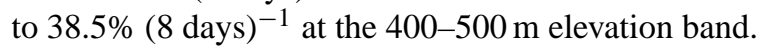

Slope and aspect affect the snow accumulation and snowmelt owing to different radiation and energy balances, as well as potentially to different accumulation regimes due to windward/leeward effects. Twelve different combinations of slope and aspect in the QRB are listed in Table 2. The west-facing areas account for about $27.9 \%$ of the QRB followed by $24.6 \%, 23.8 \%$, and $23.7 \%$ for south-facing, northfacing, and east-facing aspects, respectively. Figure 5 shows the average annual cycle of SCF for different slopes and aspects. From September to March, the east-facing areas always have the most SCF in all the slopes, which may be the result of enhanced precipitation and/or preferential snow redistribution by wind. In areas with slopes $<5^{\circ}$, the southfacing aspects always have the lowest SCF from September to March. In areas with slopes $>5^{\circ}$, south-facing areas always have the lowest SCF in September, October, November, and March along with the lowest SCF in north-facing areas in December, January, and February. In addition, the maximum differences of SCF between different aspects from September to March are 9.9\%, 13.1\%, and $19.3 \%$ for the areas with slope $<5^{\circ}, 5^{\circ}-15^{\circ}$, and $>15^{\circ}$, respectively. During the snowmelt season from March to June, the north-facing (south-facing) areas always experience the most (least) SCF for all slopes. This is partly because the snow cover on the north-facing (south-facing) areas receives less (more) solar insolation and thus melt slower (faster) than over flat terrain. The maximum difference of SCF between north-facing and south-facing areas during the snowmelt season are 6.9\%, $13.1 \%$, and $20.9 \%$ for slopes $<5^{\circ}, 5^{\circ}-15^{\circ}$, and $>15^{\circ}$, respectively.

\subsection{Relationships between topography and SCD}

The SCDs for different seasons at each pixel are calculated every year. Since there are no data prior to 14 February 2000, the mean SCDs for different seasons of each pixel cover only 2001 to 2007 (Fig. 6). The left panel of Fig. 6 presents results from the original MOD10A2 product, whereas the right panel shows results from the SF data. Despite similar trends, there are some notable differences in the values of SCDs. For the higher areas in the northeastern portion of the QRB, the spatially-filtered SCD exhibits a much larger perennial snow cover than does the original MODIS data.

The topographical control on SCD is clearly illustrated in Fig. 7. The maximum differences of SCDs between SF and MOD10A2 are 15, 15, and 42 days for the snow onset, snowmelt, and entire year periods, respectively, with the SF method always indicating a longer SCD. Points showing significant decreases in SCD at elevations of $730 \mathrm{~m}$ are associated with Quesnel Lake (Fig. 1). Table 3 lists quantitative information on the relationship between SCD and elevation. The SCD based on the SF shows higher correlations to elevation than the original MOD10A2 data. The correlation coefficients between SCD and elevation are all $>0.96$ 


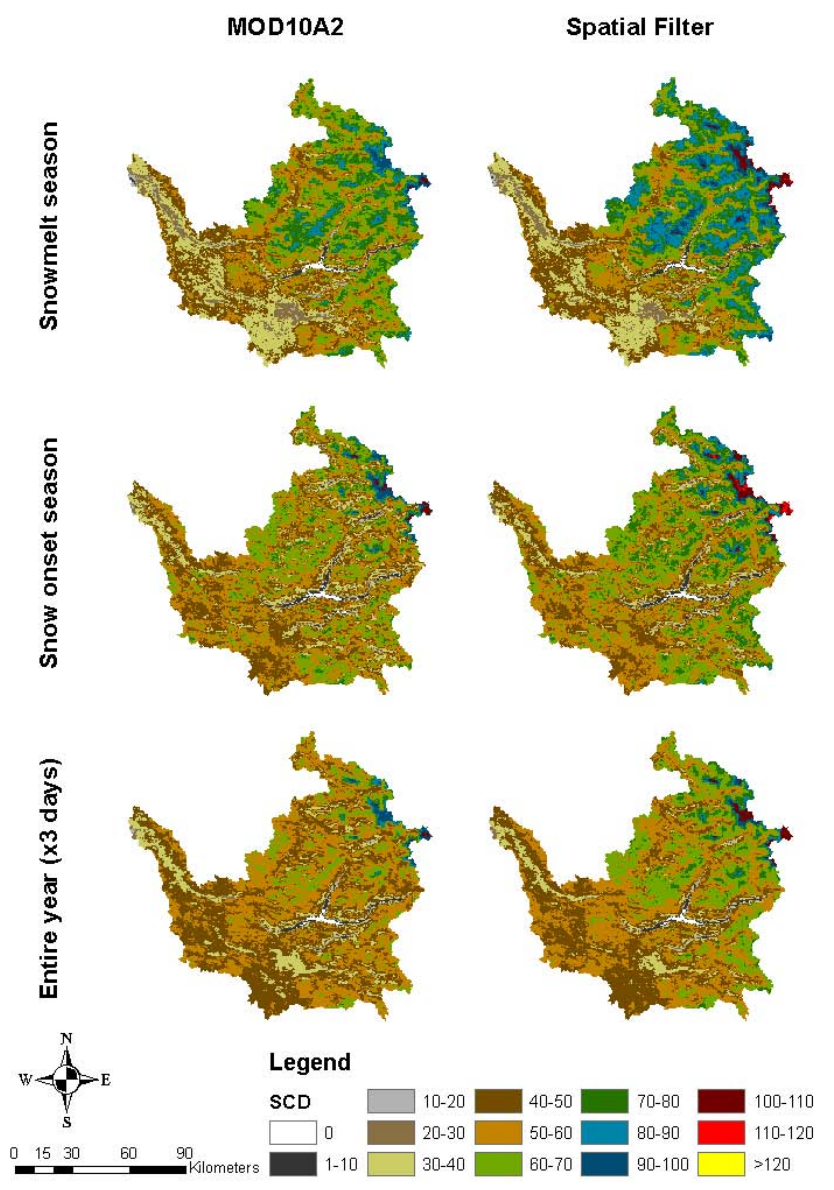

Fig. 6. The snow cover duration (SCD) for different periods across the Quesnel River Basin based on the MOD10A2 (left) and spatial filtered (right) products, 2001-2007. The SCD days for the entire year equal 3 times the values in the legend.

$(p<0.001)$. The mean values of $\mathrm{d}(\mathrm{SCD}) / \mathrm{d} z$ for the snowmelt season are 4.3 days $(100 \mathrm{~m})^{-1}$ and 3.8 days $(100 \mathrm{~m})^{-1}$ for MOD10A2 and SF, respectively. The difference of mean values of $\mathrm{d}(\mathrm{SCD}) / \mathrm{d} z$ between the SF and MOD10A2 is about 0.5 day $(100 \mathrm{~m})^{-1}$ for all snow seasons with the former exhibiting larger gradients. The standard deviations of SCDs for every $10 \mathrm{~m}$ elevation band from 2001 to 2007 for different snow seasons are also shown in Fig. 7. For both MOD10A2 and SF, the standard deviations increase with elevations lower than about $1000 \mathrm{~m}$, then decrease with elevations from $1000 \mathrm{~m}$ to $1500 \mathrm{~m}$ for all time periods. In the elevations $1500-2000 \mathrm{~m}$, the standard deviations increase again for all time periods. For the elevations $>2000 \mathrm{~m}$, the standard deviations in the snowmelt season and entire year continue increasing; however, the standard deviations in the snow onset season decrease due to perennial snow above $2000 \mathrm{~m}$ a.s.l. In this circumstance the standard deviation of SCD at the snow onset season will therefore be lower compared to that at lower elevations. The standard deviations from MOD10A2

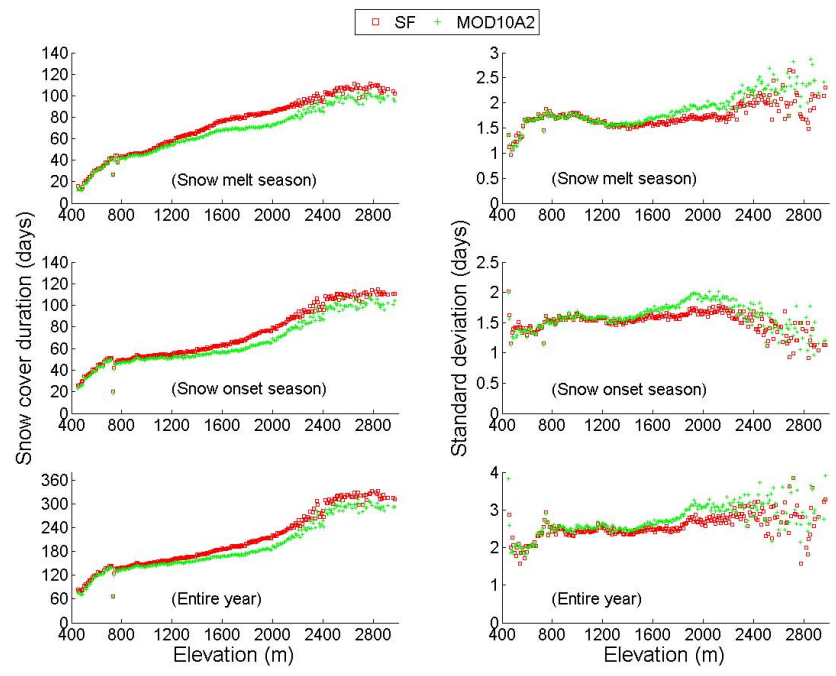

Fig. 7. The mean (left) and standard deviations (right) of snow cover durations for 10-m elevation bands for 3 seasons based on the MOD10A2 and spatial filtered products, 2001-2007.

Table 3. The correlation coefficients $(p<0.001)$ between snow cover durations and elevations within different periods and the corresponding $\mathrm{d}(\mathrm{SCD}) / \mathrm{d} z$ (days $\left.(100 \mathrm{~m})^{-1}\right)$ in parentheses.

\begin{tabular}{llll}
\hline & $\begin{array}{l}\text { Snowmelt } \\
\text { season }\end{array}$ & $\begin{array}{l}\text { Snow onset } \\
\text { season }\end{array}$ & Entire year \\
\hline SF & $0.99(4.31)$ & $0.96(3.76)$ & $0.96(11.61)$ \\
MOD10A2 & $0.98(3.94)$ & $0.93(3.42)$ & $0.94(11.26)$ \\
\hline
\end{tabular}

are larger than those of the SF with a maximum difference around 0.6 day, 0.9 day, and 1.0 day for the snow onset season, snowmelt season, and entire year, respectively.

\section{Concluding discussion}

Clouds often prevent the application of optical remote sensing to detect snow cover, especially in mountainous terrain. Although MOD10A2 decreases cloud coverage significantly compared to MOD10A1, the SCFs still show temporal discontinuities due to cloud coverage. A spatial filter reduces the cloud coverage from about $20 \%$ in the original MOD10A2 product to about $10 \%$ and provides increased accuracy from $81.3 \%$ of MOD10A2 to $83.8 \%$ of SF in mapping snow cover over the complex topography of the QRB. In this paper, the fractions of points that are in-filled by the SF range from $0 \%$ to $10 \%$ at most. Furthermore, the standard deviations of the elevation for every $3 \times 3$ cells around every center pixel indicate that the distribution of elevations of the neighboring $3 \times 3$ cells is relatively homogeneous compared to the elevation of the center pixel (not shown). Therefore, 
application of the SF method using information from neighboring cells did not seem to change the distribution trends of snow cover fraction and snow cover duration. Any differences that are introduced by the SF would cause increased variance in the results, but should not bias the average for a particular slope, aspect or elevation, especially when averaged over a very large number of pixels.

Snow cover shows significant temporal variability at different elevations. Based on the SF, the SCFs in all elevations found in the QRB reach the expected wintertime maximum of over $95 \%$ and attain a summertime minimum of about $5 \%$ for the area under $2000 \mathrm{~m}$, and a summertime minimum of about $15 \%$ for the area from $2000-2500 \mathrm{~m}$. The SF data show a larger SCF than MOD10A2 owing to the elimination of clouds. The SCFs of the SF in the area over $2500 \mathrm{~m}$ are always near $95 \%$ during winter and near $85 \%$ during summer, suggesting the presence of perennial snow cover and/or glaciers there. Fog, shadowing, and/or low illumination in valleys or on shaded slopes in mountainous terrain may contribute to erroneous surface mapping such as the appearance of snow at lower elevations during summer.

The SCF depletion curves from $10 \%$ to $80 \%$ are almost linear with a gradient of SCF with elevation $(\mathrm{d}(\mathrm{SCF}) / \mathrm{d}(z))$ of about $8 \%(100 \mathrm{~m})^{-1}$ during snowmelt seasons. At elevations from $500 \mathrm{~m}$ to $1500 \mathrm{~m}$, the average ablation rates of SCF from 26 February to 26 June for different 100 m elevation bands are similar with $5.5 \%(8 \text { days })^{-1}$ with decreasing values to near $0 \%(8 \text { days })^{-1}$ at elevations $>2500 \mathrm{~m}$. Within every given $100 \mathrm{~m}$ elevation band, ablation rates of SCF at every 8 days are very different from each other. However, the highest ablation rates of SCF at every elevation band always occur on 14 March with a maximum value of $38.5 \%$ at the 400-500 m elevation band. Slopes and aspects also affect the SCF annual cycle significantly. During the snow seasons from September to the following March, the east-facing areas always have the most SCF in all the slopes; however, the north-facing areas always have the most SCF in all the slopes during snowmelt seasons. The maximum difference resulting from different slopes and aspects is $20.9 \%$ when comparing the SCF between south-facing areas and north-facing areas on 17 May.

The SCDs show considerable spatial variability based on their 2001-2007 averages owing to the complex topography in the QRB. The longest snow seasons occur in the mountainous regions of the QRB, with decreasing SCDs from east to west along the steep gradient in elevation. The shortest SCDs occur over Quesnel Lake that does not freeze in winter. Based on the SF, the mean values of $\mathrm{d}(\mathrm{SCD}) / \mathrm{d} z$, are 3.8 days $(100 \mathrm{~m})^{-1}, 4.3$ days $(100 \mathrm{~m})^{-1}$, and 11.6 days $(100 \mathrm{~m})^{-1}$ for the snow onset season, snowmelt season and entire year, respectively. However, since the MOD10A2 data can only obtain maximum values of 106 days, 103 days, and 310 days for snow onset season, snowmelt season and entire year, respectively, the mean values of $\mathrm{d}(\mathrm{SCD}) / \mathrm{d} z$ are about 0.5 days $(100 \mathrm{~m})^{-1}$ less than those from SF data. Owing to the cloud coverage, SCDs of MOD10A2 vary more greatly than those of the SF from year to year in the different elevations. The mean values of $\mathrm{d}(\mathrm{SCD}) / \mathrm{d} z$ for the snowmelt season in the QRB are comparable to values of 5.4 days $(100 \mathrm{~m})^{-1}$ in the Eastern Alps (McKay and Gray, 1981) and 3.4 days $(100 \mathrm{~m})^{-1}$ in the central Canadian Arctic tundra $\left(66-74^{\circ} \mathrm{N}\right.$, $80-120^{\circ} \mathrm{W}$ ) (Brown et al., 2007).

Compared to other work on the SCF temporal variations in places such as the Tibetan Plateau (Pu et al., 2007) and Upper Rio Grande River Basin (Zhou et al., 2005), our research reduces the cloud coverage in the MODIS snow products to improve their quality. Even though some results of snow simulations and observations have discussed the heterogeneity of snow distributions, they have mainly focused on small or local areas of about $150 \mathrm{~km}^{2}$ or less (e.g., Blöschl et al., 1991; Déry et al., 2004). However, those methods are not necessarily suitable for a larger domain such as the QRB. Although Baral and Gupta (1997) have used some remotely sensed data to explore the relationships between topography and snow distribution, they only compare SCE with differences in slope and aspect and not SCF and SCD as was done in the present study. However, SCE is not the best method to evaluate the snow distribution owing to the different percentages of various slopes and aspects. Our research takes advantage of the MODIS snow products for assessing SCF and SCD across larger areas. The temporal and spatial distributions of SCF and SCD instead of SCE in different elevations, slopes and aspects in the QRB reveal with accuracy the topographic controls of snow distribution in complex mountainous terrain. Future work may provide further details on the relationships between the distribution and persistence of snow cover, hydrometeorology and topography of alpine basins as the resolution of snow products and DEMs improves. As an example, Tong et al. (2009) show that there exits significant anticorrelations between MODIS normalized SCE and normalized streamflow based on gauge observations during snow melt seasons in the QRB, with more significant relations when the SF method (rather than the original MODIS product) is used.

Acknowledgements. Supported by the Natural Sciences and Engineering Research Council of Canada and the Canada Research Chair program of the Government of Canada. The authors also thank D. Hall and G. Riggs (NASA GSFC) for comments on the MODIS snow products, and J. Parajka, two anonymous reviewers, and the editor R. Merz for their constructive comments on this paper. This is contribution 5 in the Quesnel River Research Centre Publication Series.

Edited by: R. Merz 


\section{References}

Baral, D. J. and Gupta, R. P.: Integration of satellite sensor data with DEM for the study of snow cover distribution and depletion pattern, Int. J. Remote Sens., 18, 3889-3894, doi:10.1080/014311697216711, 1997.

Barnett, T. P., Adam, J. C., and Lettenmaier, D. P.: Potential impacts of a warming climate on water availability in snow-dominated regions, Nature, 438, 303-309, doi:10.1038/nature04141, 2005.

Blöschl, G., Kirnbauer, R., and Gutknecht, D.: Distributed snowmelt simulations in an alpine catchment 1 . Model evaluation on the basis of snow cover patterns, Water Resour. Res., 27(12), 3171-3179, 1991.

Brown, R. D.: Northern hemisphere snow cover variability and change 1915-1997, J. Clim., 13, 2339-2355, 2000.

Brown, R. D.: Snow cover variability and trends in the Mackenzie Basin, 1945-2005, in: Final Report of the Mackenzie GEWEX Study (MAGS): Proceeding of the Final (11th) Annual Scientific Meeting, edited by: di Cenzo, P., 319-337, 2006.

Brown, R., Derksen, C., and Wang, L.: Assessment of spring snow cover duration variability over northern Canada from satellite datasets, Remote Sens. Environ., 111(2-3), 367-381, doi:10.1016/j.rse.2006.09.035, 2007.

Déry, S. J., Salomonson, V. V., Stieglitz, M., Hall, D. K., and Appel, I.: An approach to using snow areal depletion curves inferred from MODIS and its application to land surface modelling in Alaska, Hydrol. Proc., 19, 2755-2774, doi:10.1002/hyp.5784, 2005.

Déry, S. J. and Brown, R. D.: Recent Northern Hemisphere snow cover extent trends and implications for the snow-albedo feedback, Geophys. Res. Lett., 34, L22504, doi:10.1029/2007GL031474, 2007.

Déry, S. J., Crow, W. T., Stieglitz, M., and Wood, E. F.: Modeling snow-cover heterogeneity over complex Arctic terrain for regional and global climate models, J. Hydrometeorol., 5, 33-48, 2004.

Groisman, P. Y., Knight, R. W., Karl, T. R., Easterling, D. R., Sun, B., and Lawrimore, J. H.: Contemporary changes of the hydrological cycle over the contiguous United States: Trends derived from in situ observations, J. Hydrometeorol., 5, 64-85, 2004.

Hall, D. K.: Assessment of polar climate change using satellite technology, Rev. Geophys., 26, 26-39, 1988.

Hall, D. K. and Riggs, G. A.: Accuracy assessment of the MODIS snow-cover products. Hydrol. Proc., 21(12), 1534-1547, 2007.

Hall, D. K., Riggs, G. A., and Salomonson, V. V.: Development of methods for mapping global snow cover using moderate resolution imaging spectroradiometer data, Remote Sens. Environ., 54(2), 127-140, 1995.

Hall, D. K., Riggs, G. A., Salomonson, V. V., Digirolamo, N. E., and Bayr, K. J.: MODIS snow-cover products, Remote Sens. Environ., 83, 181-194, 2002.
Hall, D. K., Foster, J. L., Verbyla, D. L., Klein, A. G., and Benson, C. S.: Assessment of snow-cover mapping accuracy in a variety of vegetation-cover densities in central Alaska, Remote Sens. Environ., 66(2), 129-137, 1998.

Jain, S., and Lall, U.: Magnitude and timing of annual maximum floods: Trends and large-scale climatic associations for the Blacksmith Fork River, Utah, Water Resour. Res., 36(12), 36413651, 2000.

McKay, G. and Gray, D.: Chapter 5: The distribution of snow cover, The Handbook of Snow, Pergamon Press, Toronto, edited by: Gray, D. and Male, D., 153-190, 1981.

Mote, P. W.: Climate-driven variability and trends in mountain snowpack in Western North America, J. Clim., 19, 6209-6220, 2006.

Neumann, N. N., Derksen, C., Smith, C., and Goodison, B.: Characterizing local scale snow cover using point measurements during the winter season, Atmos.-Ocean, 44(3), 257-269, 2006.

Parajka, J. and Blöschl, G.: Spatio-temporal combination of MODIS images-potential for snow cover mapping, Water Resour. Res., 44, W03406, doi:10.1029/2007WR006204, 2008.

$\mathrm{Pu}, \mathrm{Z} ., \mathrm{Xu}, \mathrm{L}$. , and Salomonson, V. V.: MODIS/Terra observed seasonal variations of snow cover over the Tibetan Plateau, Geophys. Res. Lett., 34, L06706, doi:10.1029/2007GL029262, 2007.

Riggs, G. A., Hall, D. K., and Salomonson, V. V.: MODIS snow products user guide for collection 5 data product, http:// modis-snow-ice.gsfc.nasa.gov/sug_main.html, November 2006.

Schmugge, J. T., Kustas, W. P., Ritchie, J. C., Jackson, T. J., and Rango, A.: Remote sensing in hydrology, Adv. Water Resources, 25, 1367-1385, 2002.

Stone, R. S., Dutton, E. G., Harris, J. M., and Longenecker, D.: Earlier spring snowmelt in northern Alaska as an indicator of climate change, J. Geophys. Res., 107(D10), doi:10.1029/2000JD000286, 2002.

Tong, J., Déry, S. J., and Jackson, P. L.: Interrelationships between MODIS/Terra remotely sensed snow cover and the hydrometeorology of the Quesnel River Basin, British Columbia, Canada, in preparation, 2009.

Wang, L. B., Sharp, M., Brown, R., Derksen, C., and Rivard, B.: Evaluation of spring snow covered area depletion in the Canadian Arctic from NOAA snow charts, Remote Sens. Environ., 95, 453-463, 2005.

Yang, D., Robinson, D., Zhao, Y., Estilow, T., and Ye, B.: Streamflow response to seasonal snow cover extent changes in large Siberian watersheds. J. Geophys. Res., 108(D18), 4578, doi:10.1029/2002JD003149, 2003.

Zhou, X., Xie, H., and Hendrickx, M. H.: Statistical evaluation of remotely sensed snow-cover products with constraints from streamflow and SNOTEL measurements, Remote Sens. Environ., 94, 214-231, 2005. 